\title{
IV. 血液
}

\section{1. 白血病}

\section{九州大学医学部第一内科 仁保暿嘻之}

はじめに

昨今の医学の進歩は, 白血病に関する病因の解 明, 診断, 治療についても新しい知識をもたらし, 不治の病といわれていた本疾患も治癒率が向上し つつある。これら最近の情報について簡略に解説 したい.

\section{1. 診断と分類}

\section{1）一般的分類と頻度}

骨髄性とリンパ性白血病は各々急性と慢性に分 けられるが，単に臨床経過の速度のみならず病態 そのものが大きく異なる. 急性白血病と慢性白血 病の比は約 $7: 3$ であり, 急性白血病の 1 日推計 患者数は約 3000 人である.

ぞの年齢層にも発生するが急性骨髄性白血病 （AML）は50歳以上に多く, 急性リンパ性白血病 は (ALL) 10歳末満に多い.急性白血病の年間死 亡数は約 2800 人であり, 死亡率は人口 10 万対約 2.3 である。

これらの他に特殊な型として，慢性骨髄単球性 白血病, 赤白血病, 巨核芽球性白血病, 形質細胞 白血病, 成人 $\mathrm{T}$ 細胞性白血病, 混合型白血病 (hybrid leukemia) などが存在する.

2) FAB (French-American-British) 分類 ${ }^{1)}$ 急性白血病については, 仏, 米, 英の 3 力国の 研究者が共同して提案したFAB分類がよく用い られる(表 1). ギムザ染色とペルオキシダーゼ （PO)染色を基本にして, 客観的な診断基準を取り 入れている。

\section{2. 白血病芽球の増殖}

正常造血に执いては，多能性造血幹細胞から多 方面の造血細胞へ分化・増殖し, 成熟血球へと向 らことはすでによく知られているが, 白血病細胞
表 1. 急性白血病のFAB分類 ${ }^{11}$

（原案を大幅に簡略に書き直したもの）

PO（ペルオキシダーゼ）染色陽性率 $3 \%$ 以上を骨䯣 型とし，それ以下をリンバ型とする.

（）急性白血病のリンパ型の分類

$\mathrm{L}_{1}$ : 小型で均一. 小児に多く比較的予後良好

$\mathrm{L}_{2}$ : 大型で不均一，成人に多く予後不良.

$\mathrm{L}_{3}$ ：大型で細胞質は好塩基性, 空胞多い.いわいる Burkitt型. B細胞性，予後は最も悪い。

（II）急性白血病の骨䯣型の分類

$\mathrm{M}_{1}$ : 未分化型 芽球の $3 \%$ 以上がベルオキシダー セ陽性

$M_{2}$ ：分化型 骨髄芽球十前骨㖪球 $\geqq 50 \%$

$\mathrm{M}_{3}$ : 前骨䯣珄白血病 Auer小体や顆粒が多い

$\mathrm{M}_{4}$ : 骨䯣単球性白血病 単球十前単球 $\geqq 20 \%$, 骨髄 芽球十前骨檤球 $\geq 20 \%$

$\mathrm{M}_{\mathbf{5}}$ ：単球性白血病 エステラーセ染色陽性,骨䯣芽 球十前骨檤球 $\leqq 20 \%$

$\mathrm{M}_{6}$ ：赤白血病 赤芽球 $\geqq 50 \%$ ，異型性赤芽球の存 在，骨髄芽球十前骨䯣球 $\geqq 30 \%$

$\mathrm{M}_{7}$ ：巨核芽球性白血病 芽球 $\geqq 30 \%$, 血小板ペル才 キシダーゼ陽性

の増殖においても, 白血病幹細胞が存在すること が, multilineage leukemia (hybrid leukemia) の症例から伺らことができる2).ささざまなサイ トカインと白血病芽球増殖との関連も次第に解明 されつつある゙'.

\section{1) 自律的増殖}

刺激因子の存在なしに白血病細胞が自律的に増 殖する機構の一つの可能性は非チロシンキナーゼ 型のガン遺伝子が活性化する場合で，あと一つは 白血病細胞のレセプター異常による自律的増殖で ある。

非チロシンキナーゼ型癌遺伀子であるV-myc をレトロウイルスの形で導入すると，造血因子依 
存性でめった細胞が，非依存性に変放り，自律的 な増殖をする。さらに, N-rasのpoint mutation"), C-mybのamplificationなどの異常がAML比譛 められるのでシグナル伝達系の異常と白血病発症 とが深く関わりあっていると思われる。

次に，チロシンキナーゼ型の癌遺伝子による白 血病芽球の自律的増殖刺激の例を挙げると，Cfms由来の発癌遺公子であるV-fmsをレトロウイ ルスの形で不死化細胞株(immortalized cell line) であるFDC-P1細胞に導入すると造血因子に対す る依存性が無くなり，自律的に増殖できるように なる。すなわち腫瘍化する。また，Abelson virus (abl)ならびにＶ-srcなどのチロシンキナーゼ型 癌遗伝子を用いても同じように自律增殖株が樹立 されている。これらの現象は，レセプターに何ら かの構造上の異常が生じたため，造血因子非依存 性に変化したと考方られている。

\section{2) オートクラインとパラクライン増殖}

急性骨髄性白血病の一部の症例で白血病細胞が CSF (colony stimulating factor) Dmessenger RNAを発現していることをYoung ら ${ }^{516)}$ が発表し た，そ机炕り白血病芽球がCSFを産生し，その CSFが白血病幹細胞の増殖を刺激するオートク ライン増殖機構の可能性が示唆されている。

オートクライン増殖のみならず，パラクライン 增殖を示唆する発表もある。，Griffinの報告では7), 白血病細胞がIL-1を産生し, 間質細胞からの, CSF 産生を刺激し白血病幹細胞の増殖を促進するとい 5 .

\section{3. 染色体異常}

1) $\mathbf{P h}^{1}$ (Philadelphia) 染色体

これは $9 ； 22$ 転座であり，慢性骨髄性白血病 (CML) $997 \%$ 以上に慢性期，急性期を通じて認め られる。ささらに急性リンパ性白血病の一部にも存 在する.

\section{2）急性骨髄性白血病に見られる染色体異常}

転座 $(8 ； 21,15 ； 17,9 ； 11)$, 逆座 $(3 ， 16)$, 5 欠失など

3）リンパ性白血病

転座 $(8 ; 14,11 ; 14,1 ; 19)$ ，6 欠失等

\section{4. 治療}

\section{1) 化学療法}

代謝拮抗薬，アンソラサイクリン系抗生物質， アルキル化薬, 植物性アルカロイド，醭素製郕， 副腎皮質ステロイドを組み合わせた多剤併用療法 を主と五る ${ }^{899}$ ．寛解導入療法，地固め療法，維持 療法から成る。军ず急性骨䯣性白血病に対する寛 解尊入尞法はBHAC-DMP篁法が良く用いられて いるが,これはBHAC (behenoyl araC), D (daunorubicin), 6MP(6 mercaptopurine), PSL (prednisolone) の併用である。治療 7 日目や10日 目の骨䯣穿刺所見により，追加の有無を決定する。 完全宽解が得られなければ，次に地固め療法を宽 解導入療法上り少量の薬物で施行する。

2 - 3 回の地固め療法のあと外来で, 維持療法 を少量の抗白血病薬で行い，5週後には地固め療 法と同し内容で強化療法を行い，2 年間は 5 週毎 に維持，強化療法をくり返寺。

一方，急性りンパ性白血病は, vincristine prednisoloneの併用によるVP療法や，それに adriamycinを加えたAdVPなどがある，慢性骨䯣 性白血病注怯, busulfan, hydroxyurea， $\alpha$ interferonなどが用いられる。

\section{2) 骨髄移植}

成續が向上しつつあるが10)，HLA (human leu-

\section{表 2, 白血病の治療}

1. 化学祢法 (主炕多剂併用)
a. 寛解導入療法
b. 地固療法
c。維持撩法

2. イソターフェロン

3. 補助尞法

a. 抗生物質

b. 血小板輸血

c . 濃厚赤血球輸血

d. leukapheresis

e. BRM (biological responsive modifiers)
a. $\mathrm{CSF}$
b. romurtide (muroctasin)
c. cepharantin

4. 骨噵移植 
kocyte antigen) マッチの血縁者の数が少ないの で非血縁者骨䯣ドナーデータバンクの普及が望京 れる。

\section{3）支持療法}

感染症，DIC(播種性血管内凝固症候群) に対す る治療が白血病支持療法の二大事項である．抗生 物質, 抗菌薬の発達とCSFの出現により顆粒球減 少症に対する処置が進歩しつつある。

\section{5. 骨髄異形成症候群 (MDS)}

骨䯘異形成症候群 (myelodysplastic syndrome）は，いわゆる前癌状態の一つとも考文ら れ，白血病と密接な関係をもっている ${ }^{11}$.急性白血 病のFAB分類 ${ }^{1} に よ り \operatorname{MDS} の$ 形態的定義つけが なされた。これより以前に，非定型性再生不良性 专血，前白血病，low percent leukemia，〈すぶ り型白血病，不応性貧血，鉄芽球性筫血などと， 異なった観点から呼ばれていた症例のらちのかな りの部分が含委れる疾患群をやや広くまとめた病 名と考光てよい，従ってMDSは，heterogeneous な疾患から構成され，沉血球減少を示し，血球化 さまざな形態異常を呈し，そのため種々の治療 に抵抗性の疾患である。その原因悎血幹細胞に 後天的に発生した，翼常クローンであるが，赤芽 球系，顆䊀球系，巨核球系の三系統の血球の形態 異常之成熟障害が起こり，骨髄では無効造血を呈 する。リンパ球系も異常クローンに含まれるとの 最近の報告もある。

\section{1) $\operatorname{MDS} の$ 分類}

$\operatorname{MDS}$ 次の五病型 $\left(\mathrm{FAB}^{1)}\right)$ に分類される。(1) 不応性負血 (refractory anemia:RA)，(2)鉄芽球 を伴 う RA (RA with ring sideroblasts: RARS), (3)芽球增加学伴 5 RA (RA with excess of blasts : RAEB), (4)移行期 RAEB (RAEB in transformation: RAEB- $t$ ), (5)慢性骨䯣単球性白血病 (CMMoL)の五型である.表 3 にその概略を示す。 この分類は予後の良し悪しを比較的よく反映する が, 病的芽球数の多少の他に, 複雑な染色体巽常, 骨䯣生検所見等が予後に影響を与光る因子として 報告さ机ている，表 3 の如くRAは治療不応性の 貿血だが末梢血に芽球は绖とんど見あたらない。
表 3. MDSo分類

\begin{tabular}{c|c|c|c}
\hline 病 型 & 来梢血中茅球 & 骨髄中の芽球 & 環状鉄芽球 \\
\hline RA & $<1 \%$ & $<5 \%$ & $<15 \%$ \\
RARS & $<1 \%$ & $<5 \%$ & $>15 \% *$ \\
RAEB & $<5 \%$ & $5 \sim 20 \%$ & 不 定 \\
CMMoL & $0 \sim 5 \%$ & $1 \sim 20 \%$ & 不 定 \\
RAEB-t & $\geqq 5 \% * *$ & $20-30 \% * *$ & 不 定 \\
\hline
\end{tabular}

*本邦では，赤芽球の20\%以上をRARSをする。

**Auer小体が芽球にあれば，この数字にとらわれない。

一方，RAEBでは末梢血中に芽球が $5 \%$ 末満存在 し，更にRAEB-tになると $5 \%$ 以上の芽球が存在 し，しばしばAuer小体が認められる。

これらのうち, RAとRARSは白血病化のlow risk群, RAEB-tとCMMoLはhigh risk群, RAEB は芽球の多少や環状鉄芽球の有無によりlowから high risk群迄混在している.

2) T-MDS AML

最近, de novo leukemia with trilineage myelodysplasia (T.MDS AML) という新しい夕 イプが提唱された ${ }^{12)}$.これはde novo leukemia (初発白血病)とされている症例の中に, MDSに特 徵的な形態異常を認める成熟血球が残存している 急性骨髄性白血病があり，MDSを基盤として発生 てた，いわば急性転化型であるらと考觉ている。 注意して観察するとde novo leukemia の15\% (160例中24例) はこの型であるという。これらの 症例はいずれも，末梢血と骨髄に和いて白血病芽 球のパーセントが低い傾向にある。

\section{3) $\operatorname{MDS} の$ 治療}

MDSの発症は高年者比多い㑯向があり，強力な 化学療法が一般に奏効せ奴ことが多く，血小板や 赤血球輸血を中心とした補助療法が治療の中心と なる。化学寮法に反応する症例です寛解期間は短 く，急性骨䯣性白血病 (AML)でみられたような 予後の改善は見られていない.MDSの中でも RAEBやRAEB-tの症例注白血病比進晨する可能 性が高く，白血病に進展しない例です，白血球減 少に起团寸る感染症や，血小板减少に上る出血で 治療困難な例が多い。 
以上の様に根本的な治療がないので，さまざま な工夫，例完ばAra-Cやaclarubicinの少量投与が 試みられている。これは殺細胞効果ではなく，白 血病細胞に対する分化誘導効果を祆らったもので ある，それ以来，種々の薬物が分化誘導効果を期 待して試みられてきたが，治療成績の著しい向上 は得られていない。

MDS媓型により予後が異なり，白血病化率の 低い病型では造血を刺激する薬物や分化誘導薬， 白血病へ進展する可能性の高い病型では分化誘導 薬や抗腫演薬を用いた治療が行われることが多 $\checkmark$.

MDSに対する骨䯣移植も症例が増加してきて いる、特に白血病に移行する率が高いhigh risk群 には適応があると考点られる。

\section{6. 予後}

\section{1) $\mathbf{A L L}$}

小罗例の方が成人例上り，末た $\mathrm{L}_{2} よ り \mathrm{~L}_{1}$ が予後 がよい． $\mathrm{L}_{3}$ は予後が悪い，小児では90\%が完全寛 解に入り，そのうち40－50\%が5年以上の生存が 期待され，成人では60～80\%が完全寛解に入り， その 15 - 30\%が 5 年以上の生存が期待されるよ5 になった。

2) AML

化学療法の完全寛解率は約70８0\%。ただし， その持続期間の中央值は $1 \sim 2$ 年. 再発なしに 5 年間生存するのは10～25\%程度である，第一筧解 期に同種骨髄移植を施行した場合の長期生存率は
約 45 ～60\%であり，今後とも化学療法と骨䯣移植 双方の進歩が待たれる。

\section{文献}

1) Bennett JM, et al: Proposed revised criteria for the classification of acute myeloid leukemia. Ann Intern Med 103: 626, 1985.

2) 保喜之: 白血病之幹細胞。代謝 $27: 515,1990$.

3）仁保喜之：サイトカインと白血病。血液・腫瘍科 21 : 9, 1990.

4) Hirai $\mathrm{H}$, et al: Transforming genes in human leukemia cells. Blood $66: 1371,1985$.

5) Young DC, et al: Autocrine secretion of GM-CSF in acute myeloblastic leukemia. Blood 68: 1178, 1986.

6) Okamura $S$, et al: Expression of the granulocyte/macrophage colony-stimulating factor gene in leukemic blast cells from patients with acute non-lymphocytic leukemia. Biomed Pharmacother $42: 65,1988$.

7) Griffin JD, et al: Secretion of interleukin-1 by acute myeloblastic leukemia cells in vitro induces endothelial cells to secrete colony stimulating factors. Blood $70: 1218,1987$.

8) Champlin R, Gale RP: Acute myelogenous leukemia: Recent advances in therapy. Blood $69: 1551$, 1987.

9) Frei E III : Curative cancer chemotherapy. Cancer Res $45: 6523,1985$.

10）原田実根：骨䰙移植。内科 $63: 1251,1989$.

11）石保喜之：骨䯣巽形成淀候群 (MDS)。臨床と研究 $67: 3,1990$.

12) Brito-Babapulle $F$, et al: Clinical and laboratory features of de novo acute leukemia with trilineage myelodysplasia. Brit J Haematol 66: $445,1987$. 